\title{
Penguatan Kapasitas Ibu Rumah Tangga Melalui Pemanfaatan Tanaman Obat Keluarga di Desa Kerinjing Kecamatan Tanjung Raja Kabupaten Ogan Ilir (Empowering the Capacity of Housewives through The Use of Family Medicinal Plants in Kerinjing Village, Tanjung Raja District, Ogan Ilir Rgency)
}

Ahmad Maulana ${ }^{*}$, Nurkardina Novalia ${ }^{2}$, Wahyu Aji Wijaya ${ }^{3}$

Fakultas Ekonomi, Universitas Sriwijaya, Palembang ${ }^{1 * 3}$

Fakultas Ekonomi, Universitas PGRI, Palembang ${ }^{2}$

$\underline{\text { maulanaahmad075@gmail.com }}^{1 *}, \underline{\text { nurkardina.novalia@gmail.com }}{ }^{2}, \underline{\text { wijayawahyuaji27@ gmail.com }}{ }^{3}$

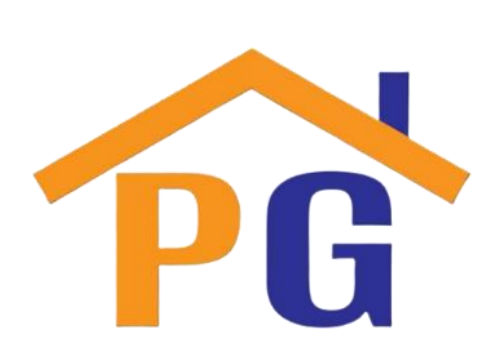

Riwayat Artikel

Diterima pada 7 May 2021

Revisi 1 pada 27 May 2021

Revisi 2 pada 28 Juni 2021

Revisi 3 pada 9 Juli 2021

Disetujui pada 22 Juli 2021

\section{Abstract}

Purpose: The Community Service Program (PKM) is located in Kerinjing Village, Tanjung Raja District, Ogan Ilir Regency. The targeted target audiences are housewives in the village. This activity aims to: (1) socialize the potential benefits of family medicinal plants (TOGA) as healthy drinks that can increase income, (2) socialize the correct way of planting family medicinal plants so that the quality is better, arousing the motivation of the target community to develop family medicinal plat processing.

Method: The methods applied in this training include counseling on several theories that support the potential and composition of family medicinal plants, how to plant and process medicinal plants into various beverage processed products, suitable packaging methods, practice, and assistance. Community service activities are carried out through lectures and demonstrations.

Results: The output produced from this activity include: (1) increased knowledge and skills of housewives regarding the use and processing of family medicinal plants, (2) increased knowledge of how to plant and pack good products, and (3) increased motivation for developing a business to use family medicinal plants.

Conclusions: After the activity, there is an increase in knowledge and skills to develop a business to use family medicinal plants, their potential, and how to process them into healthy drink products, as well as proper packaging methods. In addition, this activity also increases the motivation of housewives who are participants to develop businesses in the field of beverage products based on family medicinal plants.

Keywords: Empowerment, Housewives, TOGA, Family Welfare

How to cite: Maulana, A., Novalia, N., \& Wijaya, W. A. (2021). Penguatan Kapasitas Ibu Rumah Tangga Melalui Pemanfaatan Tanaman Obat Keluarga di Desa Kerinjing Kecamatan Tanjung Raja Kabupaten Ogan Ilir. Yumary: Jurnal Pengabdian kepada Masyarakat, 2(1), 1-8.

\section{Pendahuluan}

Mekanisme perubahan yang dilaksanakan suatu negara dengan berkesinambungan bertujuan untuk menciptakan kesejahteraan masyarakatnya disebut juga melakukan pembangunan (Teja, 2015). Semua komponen masyarakat berperan penting dalam proses pembangunan yang dilakukan, baik secara individu maupun berkelompok. Ibu rumah tangga merupakan unsur yang dapat dimanfaatkan 
dalam mendukung upaya untuk meningkatkan pendapatan rumah tangga. Selama ini kegiatan pembangunan yang terjadi lebih cenderung dikenal dengan keterlibatan kaum laki-laki. Kenyataan menunjukkan bahwa penggunaan dan pengolahan aset pedesaan lebih didominasi oleh laki-laki (Sutaryo dan Nuwandari, 2016). Kegiatan yang terkait dengan semua bidang yang berhubungan dengan pertanian, industri, menengah dan kecil, koperasi dan Usaha Mikro Kecil dan Menengah (UMKM) yang bersifat kegiatan ekonomi, diharapkan masyarakat dapat memberikan kontribusi yang besar pada kegiatan ini. Ibu-ibu rumah tangga yang berada di pedesaan memiliki hak untuk berkontribusi terhadap kegiatan pengelolaan aset pedesaan. Walaupun kadangkala kontribusi perempuan lebih sedikit daripada kontribusi laki-laki namun setidaknya perempuan bisa menjadi penggerak dalam kegiatan pengabdian ini.

Perkembangan yang terjadi pada banyak bidang sebagai dampak dari perkembangan ilmu pengetahuan IT merupakan tantangan yang cukup besar bagi perempuan, baik itu di pedesaan maupun di perkotaan dalam menggunakan manfaat dan pengelolaan lingkungan yang ada disekitarnya. Oleh sebab itu dibutuhkan suatu program-program yang mendukung kegiatan ini agar ibu-ibu tadi mampu memberikan peranannya dalam meningkatkan pendapatan keluarga dengan pemanfaatan dan pengelolaan lingkungan sekitarnya. Kondisi ini didukung oleh studi Hastuti dan Respati (2009) mengenai model pemberdayaan perempuan miskin berbasis pemanfaatan sumberdaya pedesaan sebagai upaya pengentasan kemiskinan yang mengambil lokasi di pedesaan .

Upaya peningkatan kesejaheraan keluarga yang melibatkan peran aktif kaum wanita dapat dilaksanakan dalam berbagai kegiatan dan bidang, khususnya dalam bidang pemenuhan kebutuhan pangan. Kegiatan ini merupakan kegiatan yang sudah menjadi rutinitas bercocok tanam dan memanfaatkan tanaman obat bagi keluarga di desa (Nurdiwaty, et.al, 2017). Kegiatan ini sekaligus merespon terjadinya penurunan kemampuan daya beli masyarakat sebagai dampak semakin mahalnya harga obat, sehingga berpengaruh secara tidak langsung terhadap penurunan tingkat kesehatan masyarakat. Tanaman obat keluarga adalah tanaman yang merupakan hasil pengusahaan tempat tinggal yang sangat manjur untuk penawar sakit dan dikenal dengan TOGA. Tanaman ini bisa ditanam di dalam wadah dan halaman sekeliling tempat tinggal. Apabila lahan pekarangan rumah tempat tumbuh tanaman ini cukup luas, maka hasil yang didapat ketika panen bisa ditawarkan kepada orang lain yang membutuhkannya dan pendapatannya dapat meningkatkan penghasilan keluarga. Adapun pemanfaatan TOGA bisa menjadi obat bagi keluarga sehingga dapat dimanfaatkan untuk menambah gizi bagi keluarga kecil yang menggunakan perkarangan rumahnya untuk menanam (Nugraha dan Agustiningsih, 2015). Hal inilah yang akan digerakkan lagi oleh tim pengabdian bahwa dengan menanam seperti ini memberikan juga manfaat ketersediaan rempah -rempah dipekarangan rumah serta menanam berbagai tanaman seperti bunga mawar, dahlia, sedap malam yang dapat digunakan sebagai pengharum rumah dan mempercantik rumahnya. Perkarangan rumah akan akan menjadi tampak asri dan penghuninya juga dapat memperoleh obat-obatan yang diperlukan untuk menjaga kesehatan (Muhlisah,2000)

Salah satu desa di Kecamatan Tanjung Raja, yaitu Desa Kerinjing berlokasi di Kabupaten Ogan Ilir Provinsi Sumatera Selatan. Berdasarkan observasi terdahulu, untuk penduduk yang tinggal diwilayah desa Kerinjing ini dimana kegiatan utamanya adalah pertanian dan perdagangan yang memiliki jumlah penduduk \pm 1.350 penduduk dan 470 kepala keluarga, dengan jumlah kepala keluarga seperti itu diharapkan penduduk Desa kerinjing memiliki tanaman TOGA cukup banyak. namun pada kenyataannya kegiatan menanam TOGA ini masih sangat minim (Hasugian, Vinsesnsia, 2020). Penanaman TOGA yang dilakukan Tim Pengabdian dan penduduk Desa Kerinjing setidaknya menggerakkan lagi penanaman TOGA ditiap Perumahan yang ada di Desa Kerinjing dan menggalakkan lagi khasiat tanaman-tanaman ini yang merupakan warisan dari nenek moyang kita.

Pelaksanaan sosialiasi dan pemberian pelatihan pemanfaatan serta penanaman tanaman obat keluarga (TOGA) adalah salah satu cara yang efektif dan dapat dilakukan. Kegiatan sosialisasi dan pemberian pelatihan pemanfaatan serta penanaman tanaman obat keluarga dilakukan untuk meningkatkan sikap positif masyarakat desa dalam penanaman dan pemanfaatan tanaman obat di pekarangan rumah menjadi produk obat herbal untuk meningkatkan kesehatan masyarakat. Oleh karena itu, perlu 
dilakukan program sosialisasi dan pelatihan penanaman tanaman obat keluarga untuk melestarikan budaya menanam dan memanfaatkan tanaman obat keluarga di Desa Kerinjing. Dengan adanya pelatihan ini, masyarakat dapat mengetahui beberapa jenis tanaman obat keluarga yang dapat dibudidayakan di halaman pekarangan rumah. Selain itu, dalam pelatihan ini juga dijelaskan mengenai manfaat atau khasiat dari beberapa tanaman obat keluarga serta akan diajarkan cara menanam maupun menggunakannya tanaman obat tersebut. Hal ini sejalan dengan penelitian yang dilakukan oleh Nugraha dan Agustiningsih (2015) yang berjudul "Pelatihan Tanaman Obat Keluarga (TOGA)" menjelaskan bahwa dengan membudidayakan tanaman obat keluarga (apotek hidup) sama saja melestarikan kearifan yang dimiliki oleh Indonesia. Selain itu, hasil penelitian yang dilakukan Nurdiwaty dkk (2017) yang berjudul "Pemberdayaan Wanita melalui Tanaman TOGA untuk membantu Meningkatkan Pendapatan Keluarga" bahwa tanaman TOGA bisa ditanam meskipun dengan lahan yang sangat terbatas, tanaman TOGA ternyata memberikan manfaat bagi ekonomi keluarga, baik sebagai obat yang bisa dijadikan alternatif maupun sebagai salah satu sumber penghasilan keluarga, dan ibu-ibu mampu menambah pendapatan keluarga dengan menanam tanaman TOGA sehingga bisa meningkatkan ekonomi keluarga.

Menanam tanaman obat keluarga memberikan nilai tambah bagi keluarga. Selain itu kegiatan menanaman tanaman obat keluarga ini juga memanfaatkan hasil alam yang ada di pedesaan. Pemanfaatan Tanaman TOGA ini diharapkan mampu memberikan atau meningkatkan kesejahteraan penduduk dan akan meningkatkan pendapatan penduduk desa Kerinjing melalui pengolahan secara tradisional tanaman ini seperti pembuatan jamu, makanan dan obat-obatan. Penanaman TOGA ini juga mampu menggerakkan ibu-ibu di Desa Kerinjing agar mau menanam kembali tanaman yang berkhasiat ini. Oleh karena itu dosen Jurusan Manajemn berinisiatif melaksanakan kegiatan pengabdian kepada masyarakat mengenai peranan para ibu rumah tangga untuk meningkatkan kesejahteraan melalui pemanfaatan tanaman obat keluarga di Desa Kerinjing Kecamatan Tanjung Raja Kabupaten Ogan Ilir.

Berdasarkan uraian di atas, terdapat rumusan masalah yang akan dilakukan atau dicari alternatif, dimana permasalahan yang dihadapi sebagai berikut: a) Bagaimana memberikan pengetahuan kepada ibu rumah tangga dan pemuda desa kerinjing pentingnya khasiat TOGA untuk peningkatan pendapatan dan kebutuhan sehari-hari penduduk desa kerinjing ini b) Bagaimana memberikan pengetahuan kepada ibu rumah tangga dan pemuda-pemuda didesa kerinjing tentang cara penanaman tanaman TOGA ini c) Bagaimana cara memberikan keterampilan kepada ibu-ibu rumah tangga desa kerinjing cara pengolahan tanaman TOGA ini agar dapat dikonsumsi masyarakat sebagai tanaman yang berkhasiat untuk pengobatan?

\section{Metode}

Bagian ini menguraikan metode/langkah-langkah yang digunakan dalam menyelesaikan persoalan terkait dengan kegiatan pengabdian masyarakat ini. Kegiatan ini dapat dilakukan dalam bentuk ceramah, pelatihan, dan demonstrasi. Metode evaluasi dalam kegiatan Pengabdian kepada Masyarakat ini diukur dengan pemberian kuesioner/pertanyaan kepada peserta pelatihan yaitu (pre test dan post test) pada saat sebelum dan sesudah kegiatan dilakukan. Ketercapaian serta keberhasilan dalam penelitian ini diukur dengan nilai: skor 10-20 (sangat tidak baik), 20-40 (tidak baik), 40-60 (cukup), 60-80 (baik) dan skor 80-100 (sangat baik). Penjelasan mengenai pelaksanaan kegiatan tersebut diuraikan sebagai berikut secara rinci.

\subsection{Metode Kegiatan Pengabdian pada Masyarakat}

Dalam kegiatan ini terdapat 2 (dua) metode kegiatan pengabdian yaitu: Ceramah, dengan pemanfaatan tim pengabdian untuk membimbing pelatihan yang menggunakan alat yaitu Laptop dan LCD Proyektor sebagai alat bantu agar penyampaian materi pelatihan berjalan lancar, dalam menyampaikan materi ini yaitu tentang, Khasiat tanaman obat keluarga secara ilmiah, tentang proses penanaman tanaman obat keluarga. Pemilihan metode ini dengan pertimbangan kegiatan yang dilakukan dapat memberikan materi relatif banyak secara padat, cepat dan mudah. 
Yang kedua adalah Pelatihan ini dengan menunjukkan cara bagaimana pembuatan atau penanaman bahan tanaman yang akan digunakan sebagai obat serta bagaimana tanaman itu di olah untuk dijadikan obat. Cara yang dilakukan tim pengabdian bagaimana mempraktekkannya sebagai narasumber wajib mendemonstrasikan bagaimana tanaman tersebut ditanam dan bagaimana tanaman tersebut diolah untuk dijadikan bahan minuman.

\subsection{Tahapan Pelaksanaan Kegiatan Pengabdian pada Masyarakat}

Tahapan pelaksanaan kegiatan pengabdian pada masyarakat ini meliputi langkah-langkah sebagai berikut. Tahapan yang pertama adalah Persiapan, pada tahapan ini dilakukan perencanaan program kegiatan mencakup penyelarasan dengan pengelola desa dimana tempat kegiatan dilaksanakan, penentuan jadwal atau waktu pelatihan, penentu obyek dan target partisipan pelatihan, dan perancangan substansi training.

Tahapan yang kedua ini adalah dalam pelaksanaannya kegiatan tahapan kedua ini memberikan pengetahuan mengenai bagaimana untuk menambah pemahaman dan pengetahuan dari ibu-ibu rumah tangga tentang bagaimana khasiat dari tanaman TOGA ini sebagai obat keluarga yang diajarkan dari turun temurun nenek moyang masyarakat Indonesia. Serta bagaimana cara untuk meningkatkan pengetahuan dalam mengolah tanaman obat ini menjadi minuman yang berkhasiat dalam mengobati penyakit, cara pengolahan ini diberikan dengan cara pelatihan kepada ibu-ibu rumah tangga. Pelatihan ini diberikan oleh TIM kegiatan pengabdian untuk penyamaan persepsi dengan peserta. Pelaksanaan pelatihan ini menggunakan sarana dan prasarana yang dapat memudahkan ibu-ibu rumah tangga desa kerinjing ini dalam meningkatkan pengetahuan dan keterampilannya. Kegiatan ini memberikan masukan berupa materi terlebih dahulu agar ibu-ibu rumah tangga tersebut dapat mengerti atau menambah pengetahuan mereka mengenai khasiat tanaman obat ini. Pengetahuan yang diberikan berupa pemberian makalah kepada ibu-ibu rumah tangga bagaimana khasiatnya dan juga bagaimana cara pengolahan tanaman obat ini. Makalah ini juga berisikan aneka ragam tanaman obat dan khasiatnya untuk pengobatannya.

\subsection{Aspek Pendukung dan Penghambat Kegiatan}

Adapun faktor yang mendukung dan menghambat dalam pelaksanaan kegiatan pengabdian pada masyarakat ini adalah: Faktor pendukung, instrumen yang termasuk pada factor pendukung ini adalah Kepala Desa Kerinjing, yang sebagai mendukung pelaksanaan kegiatan pengabdian. yang kedua adalah Ibu Kepala Desa Kerinjing, yang membantu kelancaran dan kesuksesan kegiatan pengabdian. Terakhir adalah semangat ibu-ibu rumah tangga Desa Kerinjing sebagai partisipan dalam pelatihan. Faktor penghambat yang menjadi permasalahan dalam kegiatan pengabdian ini yaitu keterbatasannya waktu pelaksanaan kegiatan pengabdian di Desa Kerinjing.

\subsection{Deskripsi Tugas Tim Pengabdian pada Masyarakat}

Teknik ceramah yang kolaborasikan dengan penggunaan laptop dan LCD proyektor digunakan untuk penyampaian materi tentang khasiat tanaman obat keluarga secara ilmiah, Penanaman tanaman obat keluarga, dan Pengolahan tanaman obat keluarga disampaikan oleh ketua dan dibantu oleh anggota tim.

\section{Hasil dan Pembahasan}

\subsection{Pelaksanaan Kegiatan Pengabdian pada Masyarakat}

Program ini dilaksanakan melalui dua tahap kegiatan, yaitu persiapan dan pelaksanaan. Tahap persiapan adalah tahap dimana dilakukan perancangan program pengabdian yang dilakukan melalui kegiatan sebagai berikut, yang pertama tahapan Koordinasi dengan pihak desa dimana lokasi kegiatan pengabdian. Sebelum memulai kegiatan dilakukan penyelarasan dengan pihak desa melalui Kepala Desa Kerinjing. Pengelola desa membantu program pengabdian guna memanfaatkan skill dan waktu luang para ibu rumah tangga serta akan dapat mempercepat terwujudnya kesejahteraan masyarakat desa. Tahapan yang kedua, adalah Penentuan jadwal atau waktu pelaksanaan pelatihan.

Tahapan ketiga adalah Pemilihan target peserta kegiatan pelatihan. Koordinasi yang dilakukan dengan Ibu Kepala Desa Kerinjing menentukan target dan sasaran peserta kegiatan pelatihan adalah 
ibu-ibu rumah tangga yang tinggal dan berdomisili di Desa Kerinjing. Target jumlah peserta yang dilibatkan dalam kegiatan pelatihan minimal berjumlah 30 orang.dan tahapan yang keempat adalah Perencanaan materi kegiatan pelatihan. Tim pengabdian membuat perencanaan materi kegiatan pelatihan yang meliputi wawasan dan pengetahuan mengenai ragam varian tanaman obat-obatan serta penawarnya, metode penanaman tanaman obat yang benar, dan bagaimana pengelolaan tanaman obat menjadi bahan minuman yang sehat dan enak.

Selanjutnya tahap persiapan diteruskan dengan pelaksanaan kegiatan pengabdian. Prosedur pelaksanaan kegiatan pengabdian pada masyarakat ini dapat diuraikan, yaitu yang pertama adalah Kegiatan pengabdian yang bertujuan untuk memberdayakan ibu rumah tangga di Desa Keriniing ini dilaksanakan berdasarkan hasil kesepakatan antara tim kegiatan dengan Kepala Desa dan Ibu Kepala Desa Kerinjing. Tahapan yang kedua adalah Peserta yang mengikuti pelatihan ini sebanyak 30 orang yang dipilih atas rekomendasi dan arahan dari Ibu Kepala Desa. Tahapan yang ketiga, adalah Ibu-ibu rumah tangga yang menjadi peserta merasa senang dan semangat serta menyambut dengan terbuka kegiatan pengabdian pada masyarakat yang dilakukan oleh tim dari Fakultas Ekonomi Universitas Sriwijaya dalam kegiatan penguatan ibu rumah tangga dalam penanaman dan pemanfaatan TOGA dalam rangka peningkatan kesejahteraan keluarga.

Tahapan keempat, Kegiatan pelatihan ini menyediakan informasi antara lain konsep mengenai varian ragam tanaman obat-obatan dan khasiatnya, teknik atau metode menanam tanaman obat yang benar, dan demonstrasi pengelolaan tanaman obat menjadi bahan minuman kesehatan (seperti jahe dan temulawak). Selain itu juga materi tentang cara pengemasannya. Namun demikian penyampaian materi tersebut dilakukan semaksimal mungkin karena keterbatasan waktu. Kegiatan pelatihan juga menyediakan ruang untuk diskusi dimana terdapat berbagai pertanyaan dari para partisipan. Pertanyaannya antara lain mengenai persyaratan agar tanaman obat bisa bertumbuh subur, bagaimanakah potensi pengembangan tanaman obat, serta bagaimana pula pemecahan masalah supaya tanaman obat yang dikelola memberikan hasil yang baik dan menarik untuk dipasarkan. Puncaknya adalah kegiatan pelatihan yang memberikan materi berupa contoh-contoh tanaman obat yang berjumlah sebanyak 30 varian tanaman untuk tumbuhkembangkan di lokasi kegiatan dan berbagai wujud hasil pengolahan tanaman obat berbentuk serbuk untuk mengobati berbagai permasalahan kesehatan yang dihadapi masyarakat.

\subsection{Hasil Pelaksanaan Kegiatan Pengabdian Masyarakat}

Pelaksanaan kegiatan pengabdian pada masyarakat memberikan hasil melalui dua prosedur kegiatan, yaitu persiapan dan pelaksanaan. Langkah persiapan yang merupakan perencanaan program pengabdian dilakukan kegiatan sebagai berikut. Pertama, melakukan dengan pihak desa melalui perangkat desa dan kepala desa. Pihak masyarakat desa sangat mendukung kegiatan pengabdian yang dilakukan oleh tim sebagai upaya pemberdayaan ibu rumah tangga di wilayahnya dan diharapkan mampu mendukung kesejahteraan masyarakat Desa Kerinjing. Kedua, menentukan jadwal atau waktu kegiatan pelatihan berdasarkan kesepakatan dengan Ibu Kepala Desa Kerinjing. Ketiga, penentuan masyarakat sebagai target peserta pelatihan berkoordinasi dengan Ibu Kepala Desa Kerinjing. karena sasaran pelatihan adalah ibu-ibu rumah tangga di Desa Kerinjing, yaitu dengan target peserta pelatihan sebanyak 30 orang. Dan yang terakhir adalah Penyusunan rencana materi pelatihan, Tim pengabdian membuat perencanaan materi pelatihan yang mencakup pemahaman tentang berbagai varian tanaman obat-obatan dan khasiatnya, serta metode penanaman tanaman obat yang baik, serta pengolahan tanaman obat menjadi bahan minuman.

Selanjutnya setelah melaksanakan langkah persiapan, kegiatan memasuki tahap pelaksanaan. Program pengabdian pada masyarakat pada tahap pelaksanaan ini adalah sebagai berikut: Pelaksanaan kegiatan pengabdian pada masyarakat di Desa Kerinjing ini adalah pada hari Senin tanggal 16 November 2020 bertempat di rumah Ibu Kepala Desa ; Sebanyak 30 orang peserta mengikuti kegiatan ini yang sebagian besar adalah ibu rumah tangga atas arahan dari Ibu Kepala Desa; Selama pelaksanaan kegiatan seluruh peserta terlihat semangat dan antusias mengikuti materi demi materi yang disampaikan oleh tim pengabdian mengenai proses penanaman dan pemanfaatan tanaman obat keluarga serta khasiatnya; Beberapa materi yang diberikan oleh tim antara lain mengenai pemahaman 
tentang variasi tanaman obat-obatan dan khasiatnya, metode penanaman tanaman obat yang baik, dan demonstrasi mengolah tanaman obat menjadi minuman kesehatan, serta cara pengemasan untuk dijual. Semua materi efektif disampaikan meskipun dengan keterbatasan waktu. ; Beberapa peserta juga mengajukan pertanyaan terkait dengan materi pelatihan seperti: factor-faktor apa yang harus dipenuhi supaya tanaman obat bisa tumbuh subur, potensi pengembangan tanaman obat, serta bagaimanakah alternatif penyelesaian supaya tanaman obat yang diolah hasilnya baik dan menarik. Selain materi juga diberikan beberapa contoh jenis tanaman obat sebanyak 30 jenis pada saat kegiatan pelatihan. Tanaman obat tersebut untuk dibudidayakan di perumahan dimana lokasi kegiatan pengabdian dilakukan. Hasil tanaman obat keluarga tersebut selain untuk kesehatan alami anggota keluarga juga untuk menambah pendapatan keluarga dengan dipasarkan secara komersial.
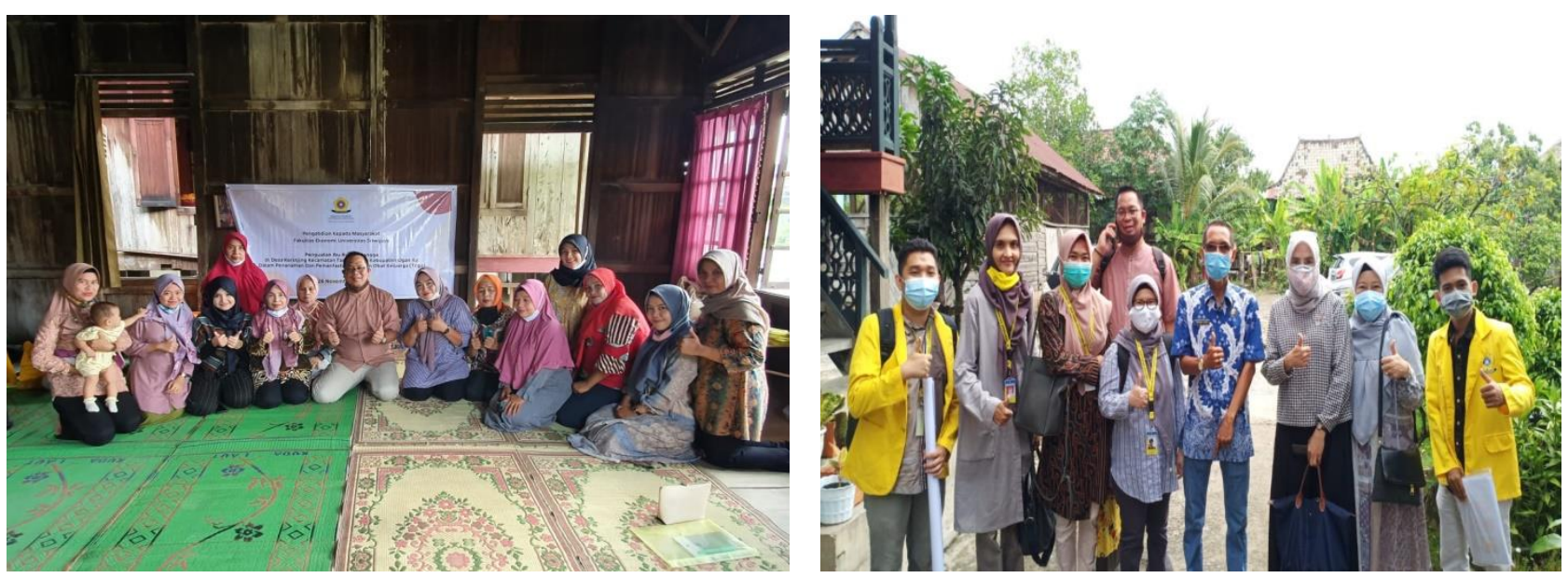

Gambar 1. Tim Pengabdian Masyarakat FE Unsri dan Peserta Pelatihan
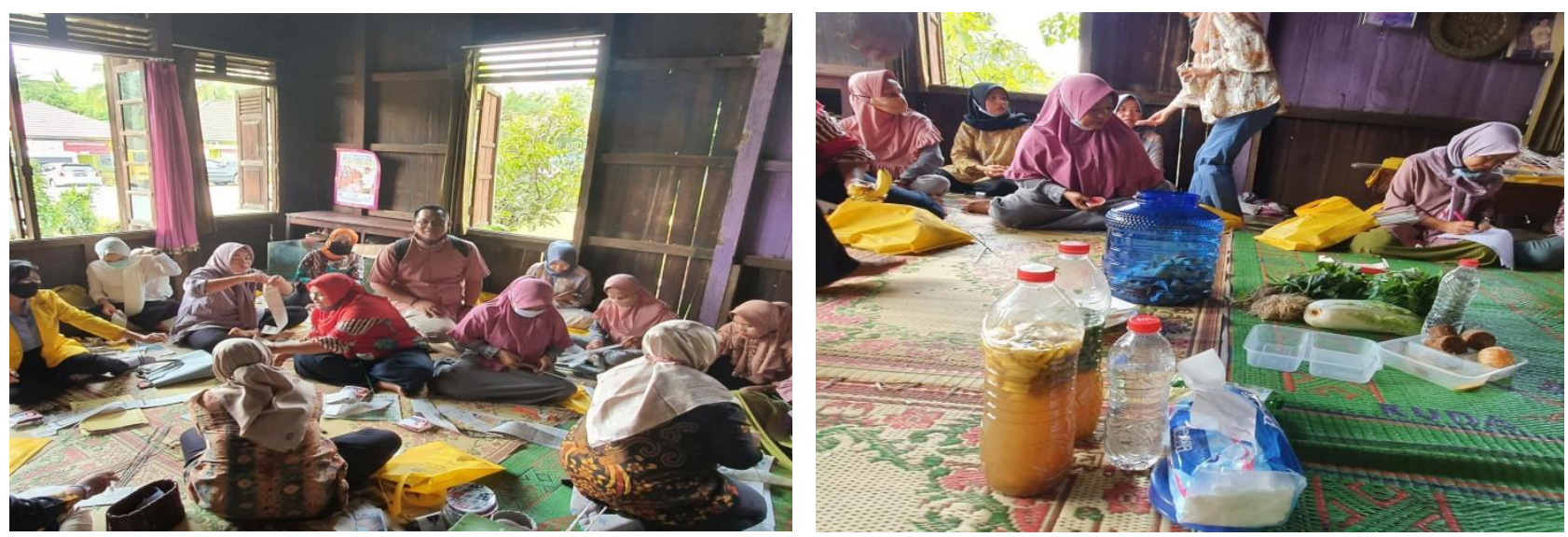

Gambar 2. Instruktur Memberikan Materi dan Praktek Mengenai TOGA

\subsection{Pembahasan Pelaksanaan Kegiatan Pengabdian pada Masyarakat}

Setelah dilaksanakan kegiatan pengabdian pada masyarakat di Desa Kerinjing dengan obyek target ibu-ibu rumah tangga, maka dapat dicermati beberapa hasil dari kegiatan yang telah dilakukan, yaitu yang pertama adalah Capaian target jumlah peserta kegiatan. Capaian target peserta yang mengikuti kegiatan pelatihan adalah 100 persen, dimana sebanyak 30 orang ibu rumah tangga menjadi peserta mengikuti kegiatan pelatihan sampai dengan selesai. Sasaran peserta dipilih berdasarkan arahan dari ibu Kepala Desa setempat. Kedua adalah Capaian tujuan kegiatan. Ketercapaian tujuan kegiatan pelatihan adalah 80 persen bisa disimpulkan baik dengan melihat hasil ukuran evaluasi pelaksanaan pelatihan menggunakan pre test dan post test . Terdapat peningkatan pengetahuan peserta tentang khasiat aneka jenis tanaman obat dan tata cara penanamannya yang baik. Selain itu pengetahuan dan 
keterampilan mengolah tanaman obat menjadi bahan minuman kesehatan yang enak dan komersial. Harapan dari program pelatihan ini bahwa ibu-ibu rumah tangga di Desa Kerinjing dapat melakukan praktek langsung kegiatan TOGA ini, sehingga dapat meningkatkan kesehatan dan kesejahteraan keluarga.Ketiga adalah Capaian target penyampaian materi yang telah direncanakan. Pencapaian sasaran materi yang direncanakan dapat disimpulkan baik (80\%). Materi yang disampaikan berupa Aneka Ragam tanaman obat yang baik, dan bagaimana cara pengolahannya menjadi minuman obat dengan waktu yang singkat namun berkat kerja keras Tim pengabdian semua berjalan lancer. Dengan tingkat pemahaman peserta yang terdiri dari ibu-ibu rumah tangga dan para pemuda yaitu 75 persen namun kami tetap membuka kemungkinan untuk bisa tetap memantau perkembangan ibu-ibu rumah tangga desa kerinjing agar dapat mengerti sampai denga 100 persen dengan cara Tim pengabdian ini bisa diskusi melalui social media yaitu WA group yang di kumpulkan oleh tim pengabdian. dapat dikatakan baik. Metode yang digunakan untuk menyampaikan materi adalah dengan ceramah dan demonstrasi sangat membantu para peserta dalam menguasai materi yang diberikan oleh tim pengabdian.

Hal tersebut sejalan yang dilakukan oleh Trinsawati, et al. (2019) bahwa " secara keseluruhan kegiatan sosialisasi dan pemberian pelatihan pemanfaatan serta penanaman tanaman obat keluarga (TOGA) yang dilaksanakan di Desa Kaliwungu, Kabupaten Kebumen berjalan dengan baik dan lancar. Kegiatan sosialisasi tersebut menggunakan metode ceramah dan demonstrasi dapat memberikan dan menambah pengetahuan tentang tata cara penanaman tanaman obat yang baik". Serta Penelitian Permatasari et.al (2019) tentang "Pemberdayaan Ibu Rumah Tangga di Kelurahan Cinere dalam Penanaman dan Pemanfaatan Tanaman Obat Keluarga". Masyarakat yang telah memiliki pengetahuan tentang khasiat TOGA dan menguasai cara pengolahannya dapat membudidayakan tanaman obat secara individual dan memanfaatkannya sehingga akan terwujud prinsp kemandirian dalam pengobatan keluarga. Selain itu juga dapat dikembangkan menjadi usaha kecil dan menengah di bidang obat-obatan herbal, yang selanjutnya disalurkan kepada masyarakat.

Berdasarkan evaluasi atas program pengabdian pada masyarakat di Desa Kerinjing di atas maka secara umum kegiatan telah dilaksanakan dengan baik dan berhasil. Hal ini dapat dilihat dari analisis pelaksanaan kegiatan sosialiasi dan pemberian pelatihan terkait Tanaman Obat Keluarga (TOGA).

\section{Kesimpulan dan Saran}

Kegiatan penguatan kapasitas ibu rumah tangga dalam pemanfaatan tanaman obat keluarga di Desa Kerinjing telah dilaksanakan dengan baik dan lancar. Hasil analisis terhadap kegiatan dapat dicermati antara lain meningkatnya pengetahuan para ibu rumah tangga. Peran ibu rumah tangga semakin kuat dalam mendukung kesehatan keluarga dan meningkatkan kesejahteraan keluarga melalui pemahaman tentang aneka jenis tanaman obat keluarga. Keterampilan penanaman dan pengolahan tanaman tersebut menjadi minuman kesehatan yang dapat meningkatkan penghasilan keluarga. Kegiatan pengabdian pada masyarakat ini diharapkan dapat mencapai tujuan akhir melalui pemberi materi pelatihan menggunakan metode ceramah dan juga demonstrasi. Selanjutnya, hasil kegiatan ini hendaknya dapat ditindaklanjuti oleh pemerintah setempat dengan dukungan seluruh masyarakat didesa sehingga, terwujudnya peningkatan kesejahteraan masyarakat desa. Tahapan berikutnya diharapkan adanya perluasan dan kedalaman materi pelatihan berupa manajemen pemasaran Toga agar dapat meningkatkan kesejahteraan keluarga.

\section{Ucapan Terima Kasih}

Tim kegiatan pengabdian pada masyarakat menyampaikan terima kasih kepada LPPM Universitas Sriwijaya, UPPM Fakultas Ekonomi Universitas Sriwijaya, dan Perangkat Desa serta segenap masyarakat Kerinjing Kecamatan Tanjung Raja, Kabupaten Ogan Ilir.

\section{Referensi}

Hastuti dan Dyah Respati SS. (2009). Model Pemberdayaan Perempuan Miskin Berbasis Pemanfaatan Sumberdaya Perdesaan Sebagai Upaya Pengentasan Kemiskinan di Perdesaan Lereng Merapi Selatan. Laporan Akhir Hibah Bersaing. Yogyakarta: UNY. 
Hasugian,P.S.,Vinsesnsia,D. (2020). Pemberdayaan Ibu Rumah Tangga Desa Sampurtoba Kecamatan Harian Kabupaten Simosir dalam Penanaman dan Pemanfaatan Tanaman Obat. Jurnal Tridarma:Pengabdian Kepada Masyarakat (PKM), 3(1).

Muhlisah,F. (2000). Tanaman Obat Keluarga (TOGA). Jakarta:Penebar Swadaya.

Nugraha, S.P \& Agustiningsih, W.R. (2015). Pelatihan Penanaman Tanaman Obat Keluarga (TOGA). Jurnal Inovasi Kewirausahaan, 4(1),58-62

Nurdiwaty,D.,Puspita,E.,Kusumaningtyas,D.,Winarko,S.P.,Tohari,A.,Solikhah,M.,Faisol. (2017). Pemberdayaan Wanita Melalui Tanaman TOGA untuk membantu Meningkatkan Pendapatan Keluarga. Jurnal ABDINUS, 1 (1),20-27.

Permatasari,P.,Hardy,F.R. (2018). Pemberdayaan Ibu Rumah Tangga di Kelurahan Cinere dalam Penanaman dan Pemanfaatan Tanaman Obat Keluarga (TOGA). Jurnal Bakti Masyarakat Indonesia, 2(1) 129-134.

Sutaryo, Nuwandari, Intan. 2016. Praktik Pengelolaan Aset Desa di Pemerintahan Desa Provinsi Jawa Tengah. Jurnal Akrual, 7(2), 140 - 162.

Teja, Mohamad. (2015). Pembangunan untuk Kesejahteraan Masyarakat di Kawasan Pesisir. Jurnal Aspirasi, 6(1).

Trisnawati,O.R.,Latifatusaniyah.,Sulasti,H. (2019). Pemberdayaan Ibu Rumah Tangga dalam Penanaman dan Pemanfaatan Tanaman Obat Keluarga (TOGA). Jurnal Ar-Rihlah. 4(1). 